\title{
Ovarian Leydig cell tumor in a post-menopausal patient with severe hyperandrogenism
}

\author{
Tumor ovariano de células de Leydig em paciente em \\ pós-menopausa com hiperandrogenismo grave
}

Selma B. Souto', Pedro V. Baptista², Daniel C. Braga', Davide Carvalho'

'Department of Endocrinology, Diabetes and Metabolism, Centro Hospitalar S. João, Porto, Portugal: Universidade do Porto, Faculdade de Medicina, Portugal 2 Department of Gynecology and Obstetric, Centro Hospitalar S. João, Porto, Portugal

\author{
Correspondence to: \\ Selma B. Souto \\ Department of Endocrinology, \\ Diabetes and Metabolism, \\ Centro Hospitalar São João, \\ Faculdade de Medicina, \\ Universidade do Porto \\ Alameda Prof. Hernâni Monteiro \\ 4200-319 - Porto, Portugal \\ sbsouto.md@mail.com \\ Received on Nov/1/2012 \\ Accepted on May/23/2013
}

\begin{abstract}
SUMMARY
Leydig cell tumors are rare ovarian steroid cell neoplasms. More than $75 \%$ of patients show signs of virilization due to overproduction of testosterone. We report a case of an 8-year-old woman with progressive signs of virilization, and presenting vaginal bleeding. Clinical analyses revealed high levels of serum testosterone, delta 4-androstenedione and estradiol, and also inappropriate low levels of gonadotrophins for a post-menopausal woman. Transvaginal ultrasound showed no evidence of ovarian tumor, but pelvic and abdominal computerized axial tomography imaging revealed a left ovarian solid nodule, and no evidence of alteration in the adrenal glands. Total hysterectomy and bilateral salpingoophorectomy were performed. Histopathology and immunohistochemistry confirmed the diagnosis of Leydig cell tumor. After surgery, androgen levels returned to normal, and there was regression of the signs of virilization. Arq Bras Endocrinol Metab. 2014;58(1):68-70
\end{abstract}

\section{SUMÁRIO}

Tumores ovarianos de células de Leydig são neoplasias raras de células ovarianas esteroidogênicas. Mais de $75 \%$ dos pacientes apresentam sinais de virilização devido à produção excessiva de testosterona. Relatamos aqui o caso de uma mulher de 81 anos de idade com sinais progressivos de virilização e ocorrência de sangramento vaginal. As análises clínicas mostraram altos níveis de testosterona sérica, delta 4-androstenediona e estradiol, além de níveis inadequadamente baixos de gonadotrofinas para uma mulher em pós-menopausa. 0 ultrassom transvaginal não apresentou evidências de tumor ovariano, mas a tomografia axial computadorizada da região pélvico-abdominal mostrou um nódulo sólido no ovário esquerdo e nenhuma evidência de alteração nas adrenais. Foi feita uma histerectomia total e salpingooforectomia bilateral. Os exames histopatológicos e a imuno-histoquímica confirmaram o diagnóstico de tumor de células de Leydig. Após a cirurgia, os níveis de androgênios voltaram ao normal, e os sinais de virilização regrediram. Arq Bras Endocrinol Metab. 2014;58(1):68-70

\section{INTRODUCTION}

$\mathrm{V}$ irilizing ovarian tumors are a rare cause of hyperandrogenism, are most frequently found after menopause, and are reported to be less than $5 \%$ of all ovarian neoplasms $(1,2)$. Leydig cell tumors account for $0.1 \%$ of all ovarian tumors, and are a type of steroid cell tumor. The majority of the cases is diagnosed in the presence of a hyperandrogenic state with signs of virilization (hirsutism, acne, deep voice, mammary atrophy, increased libido, clitoromegalia) (2-5). Occasionally, these tumors may exhibit a hyperestrogenic state, and some patients also have vaginal bleeding $(6,7)$. Virilizing Leydig cell tumors usually have a benign behavior, with an excellent prognosis and reversion of symptoms after surgical treatment (7).

\section{CASE REPORT}

The authors report a case of 81-year-old women with vaginal bleeding for the previous year. Her family referred to the rapid onset of virilization, with hirsutism, androgenetic alopecia, and deep voice, starting one year before. She had history of primary infertility, dyslipidemia, and demential syndrome, and was under therapy with atorvastatin $10 \mathrm{mg} /$ day. Family clinical history was not noteworthy. Physical examination revealed signs of virilization with hirsutism (score 15, Ferriman-Gallwey scale), androgenetic alopecia, and deep voice. Gynecological examination revealed an enlargement of the clitoris and no palpable adnexal masses. Blood pressure was $140 / 80 \mathrm{mmHg}$. She had no features of Cushing syndrome. 
Endocrine evaluation revealed hyperandrogenism, with markedly increased total serum testosterone and delta 4-androstenedione concentrations. Serum levels of luteinizing hormone ( $\mathrm{LH})$ and follicle stimulating hormone (FSH) were inappropriately low for a postmenopausal woman, with high levels of estradiol. Serum levels of dehydroepiandrosterone-sulfate (DHEA-S), 17-hidroxyprogesterone (17-OHP) and prolactin and twenty-four hours urinary free cortisol ( $24 \mathrm{hr}$-UFC) were within the normal range (Table 1 ).

Transvaginal ultrasound showed an intramural fibroid nodule, without endometrial hyperplasia, no visualization of adnexal masses, without any free fluid in the pouch of Douglas. The pelvic and abdominal computerized axial tomography (CT) showed a left ovarian solid nodule with $30 \mathrm{~mm}$ in diameter, and morfodimensional normality of the adrenal glands. No other pathologic findings were detected, namely, ascites or lymph node enlargement. Pelvic magnetic resonance image (MRI) was also performed and confirmed the ovarian solid nodule $(29.5 \times 22.8 \mathrm{~mm})$ (Figure 1). Serum tumor marker (CAl25, CA19.9, and $\alpha$-FP) levels were within the normal range, and chest X-ray and EKG were normal. Hysterectomy and bilateral salpingoophorectomy were performed, as previously discussed with the patient and her family. Histology revealed a Leydig cell tumor of the ovary. One month after surgery, androgen levels had dropped to normal levels (Table 1), and one year later, the signs of hyperandrogenism improved significantly (score 3, Ferriman-Gallwey scale), however clitoromegaly did not regress.

Table 1. Clinical analytical parameters determined before surgery, and one month after surgery

\begin{tabular}{lccc}
\hline & Before & After & Reference values \\
\hline Free testosterone & 1.181 & & $<0.015-0.155 \mathrm{ng} / \mathrm{dL}$ \\
Total testosterone & 740 & 25 & $11-78 \mathrm{ng} / \mathrm{dL}$ \\
DHEA-S & 141.0 & 73.9 & $12.0-154 \mu \mathrm{g} / \mathrm{dL}$ \\
Delta 4-androstenedione & $>10.0$ & 1.90 & $0.30-2.99 \mathrm{ng} / \mathrm{mL}$ \\
17-OHP & 1.28 & & $0.11-1.20 \mathrm{ng} / \mathrm{mL}$ \\
FSH & 16.38 & & $25.8-150.3 \mathrm{mlU} / \mathrm{mL}$ \\
LH & 15.08 & & $10.4-64.6 \mathrm{mlU} / \mathrm{mL}$ \\
Estradiol & .55 .3 & & $<5-54.7 \mathrm{pg} / \mathrm{mL}$ \\
Prolactin & 12.8 & & $1.2-29.9 \mathrm{ng} / \mathrm{mL}$ \\
24hr-UFC & 29.5 & & $36-137 \mathrm{ug} / 24 \mathrm{~h}$ \\
\hline
\end{tabular}

DHEA-S: dehydroepiandrosterone-sulfate; 17-OHP: 17-hidroxyprogesterone; LH: luteinizing hormone; FSH: follicle stimulating hormone; 24hr-UFC: twenty-four-hour urinary free cortisol.

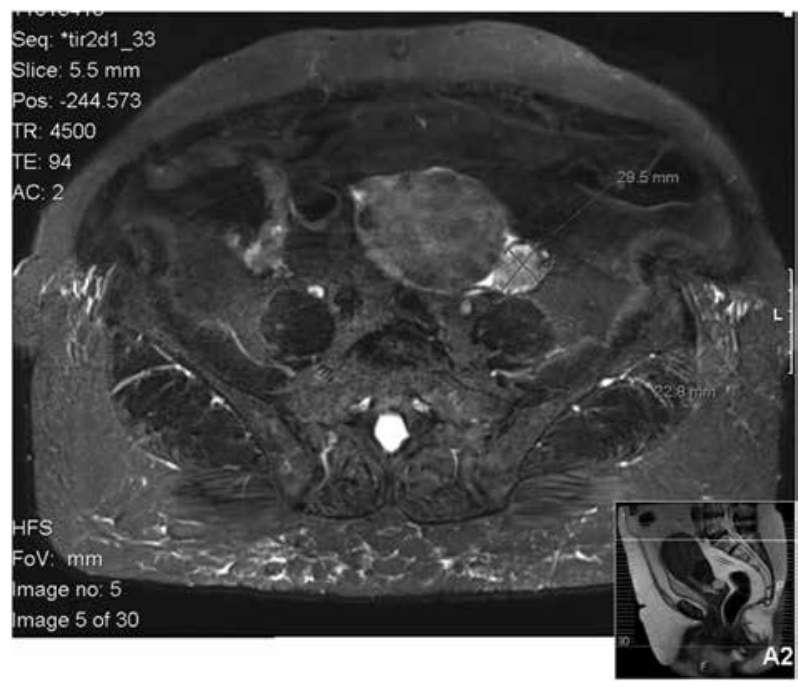

Figure 1. Pelvic MRI revealed a solid nodule of $29.5 \times 22.8 \mathrm{~mm}$ in the left ovary.

\section{DISCUSSION}

In our case, the hyperandrogenic state with rapidly progressing signs of virilization raised suspicion of a virilizing tumor. In a woman with signs of virilization, it is essential to perform a careful gynecological examination, to evaluate the presence of adnexal masses or clitoromegaly. The measurement of serum androgens is also required, in order to exclude an ovarian or adrenal androgen-producing tumor. After the menopause, ovarian causes of virilization are more common than adrenal ones (5). Many of ovarian virilizing tumors are not diagnosed for years.

In the present case, the high serum levels of total testosterone $(740 \mathrm{ng} / \mathrm{dL})$ confirmed the presence of a virilizing neoplasm, while normal serum level of DHEA-S ruled out an adrenal cause. Testosterone serum levels above $200 \mathrm{ng} / \mathrm{dL}$ should raise the suspicion of an androgen-producing tumor, and serum values of DHEA-S higher than $600 \mathrm{mg} / \mathrm{dL}$ may suggest an adrenal source (5). High estradiol levels may be due to aromatization of testosterone, resulting in endometrial hyperplasia and vaginal bleeding.

Leydig cell tumors are usually small, measuring less than $5 \mathrm{~cm}$ of diameter - just slightly bigger than a normal ovary $(2,6,8)$. It may be difficult to identify it by radiological imaging, in part because it is isoechoic to the uterus on ultrasound, and isodense on CT $(4,9)$.

Nevertheless, transvaginal ultrasound is the most sensitive method for the detection of an ovarian tumor (5); however, the accuracy of the ultrasound examination is operator-dependent. In our patient, the 
tumor was not visualized in the transvaginal ultrasound despite being $3 \mathrm{~cm}$ in diameter. Radiological imaging by CT and MRI enable the attribution of the cause to an ovarian etiology.

In a few cases of post-menopausal virilization, an ovarian venous sampling was performed to confirm the source of excess androgen (5). Considering the fact that the probability of finding an unsuspected adrenal mass in patients over 70 years of age reaches 7\%, Alpañés and cols. proposed an algorithm for the diagnosis and management of post-menopausal hyperandrogenism in which a patient without ovarian or adrenal tumor in radiological images, inconclusive results or with a small adrenal adenoma should undergo combined adrenal and ovarian sampling (5). However, simultaneous catheterization of adrenal and ovarian veins is difficult, with success rates as low as $26-45 \%(5)$.

In post-menopausal women with virilization and elevated testosterone levels, an oophorectomy should be considered after the exclusion of adrenal causes (10).

In our patient, surgical intervention enabled the final diagnosis of Leydig cell tumor. As expected, there was a return of serum androgen levels to normal values, and improvement of clinical hyperandrogenism.

Disclosure: no potential conflict of interest relevant to this article was reported.

\section{REFERENCES}

1. Stegner HE, Loning T. [Endocrine-active tumors of the ovary]. Pathologe. 2003;24(4):314-22.

2. Nardo LG, Ray DW, Laing I, Williams C, McVey RJ, Seif MW. Ovarian Leydig cell tumor in a peri-menopausal woman with severe hyperandrogenism and virilization. Gynecol Endocrinol. 2005;21(4):238-41.

3. Rachon D. Differential diagnosis of hyperandrogenism in women with polycystic ovary syndrome. Exp Clin Endocrinol Diabetes. 2012;120(4):205-9.

4. Wang PH, Chao HT, Lee RC, Lai CR, Lee WL, Kwok CF, et al. Steroid cell tumors of the ovary: clinical, ultrasonic, and MRI diagnosis--a case report. Eur J Radiol. 1998;26(3):269-73.

5. Alpañés M, González-Casbas JM, Sánchez J, Pián H, EscobarMorreale HF. Management of postmenopausal virilization. J Clin Endocrinol Metab. 2012;97(8):2584-8.

6. Aimakhu VE, Adeleye JA, Hendrickse M, de Von Hendrickse JP, lloabachie G. Masculinizing tumors of the ovary. J Natl Med Assoc. 1976;68(1):34-8.

7. Salim S, Shantha GPS, Sudhakar L. Virilizing ovarian steroid cell tumor in a 40 year old South Indian female: a case report. Cases J. 2009;2:7521.

8. Hill WE, Clark JFJ. Functional ovarian tumors: a ten year study at Freedmen's Hospital. J Natl Med Assoc. 1964;56 (1):66-70.

9. Monteagudo A, Heller D, Husami N, Levine RU, McCaffrey R, Timor-Tritsch IE. Ovarian steroid cell tumors: sonographic characteristics. Ultrasound Obstet Gynecol. 1997;10(4):282-8.

10. Hofland M, Cosyns S, De Sutter P, Bourgain C, Velkeniers B. Leydig cell hyperplasia and Leydig cell tumour in postmenopausal women: report of two cases. Gynecol Endocrinol. 2013;29(3):213-5. 